\title{
Assessment of Changes in Ice Regime Characteristics of Russian Lakes and Rivers under Current Climate Conditions
}

\author{
Valery Vuglinsky \\ St. Petersburg State University, St. Petersburg, Russia \\ Email:vvuglins@vv4218.spb.edu
}

How to cite this paper: Vuglinsky, V. (2017) Assessment of Changes in Ice Regime Characteristics of Russian Lakes and Rivers under Current Climate Conditions. Natural Resources, 8, 416-431. https://doi.org/10.4236/nr.2017.86027

Received: January 9, 2017

Accepted: June 17, 2017

Published: June 21, 2017

Copyright $\odot 2017$ by author and Scientific Research Publishing Inc. This work is licensed under the Creative Commons Attribution International License (CC BY 4.0).

http://creativecommons.org/licenses/by/4.0/

\section{(c) (i) Open Access}

\begin{abstract}
This article deals with assessment of changes in ice cover duration and maximum ice cover thickness for the last three decades compared with the previous period by the example of observation data for 28 hydrometric stations on rivers and 10 hydrological stations on lakes. Estimations of homogeneity and trends of long term serious of above mentioned rivers and lakes ice regime characteristics for three time periods were carried out using Student and Fisher criteria. Assessment of changes in ice regime characteristics for the period 1980-2010 compared with the period of stationary climate (from the beginning of observations until 1979) using two methodological approaches was made. The results can be used for solving problems of economy branches adaptation in case of rivers and lakes used in winter conditions.
\end{abstract}

\section{Keywords}

Rivers, Lakes, Ice Cover Duration, Maximum Ice Cover Thickness, Assessment of Changes, Last Three Decades

\section{Introduction}

In recent decades, the issue of assessing changes in hydrological regime of surface water bodies in a non-stationary climate has become especially relevant. Over the past 100 years, average annual temperatures on the territory of the Russian Federation have risen by $1.2^{\circ} \mathrm{C}$, which resulted in noticeable changes in hydrological regime of many rivers and lakes of the country. Studies of these changes are mainly focused on water resources and water balance of rivers as these are two major factors shaping the dynamics of water use both annually and inter-annually, which is critically important in planning and implementation of 
different water management projects in river basins. Very few studies are focused on surface water bodies' ice regime characteristics. However, it is known that such characteristics of river and lake ice regime as dates of ice-on and ice-off, duration of ice cover and ice thickness are highly important and sometimes limiting factors in winter operation of these water bodies. The dates of ice-on and ice-off and duration of ice cover determine navigation, hydraulic construction in cold period, construction of ice roads and bridges. Ice thickness is a major factor in evaluating the bearing capacity and duration of river and lakes ice bridges and roads. It is for this reason that the issue of assessing changes in ice regime of lakes and rivers, both in current and possible future climate conditions, is of undoubted importance. This issue is not being addressed; it will not be possible to maximize the efficiency of operation of rivers and lakes in cold and winter periods when ice phenomena are favorable for some economic activities and at the same time restrictive for others.

\section{Status of Research}

In the Russian Federation, research in the field of climate change impact on surface water bodies ice regime has begun relatively recently-since the early 1990s. Scientists from the Hydrometeorological centre of Russia (B.M. Ginzburg, I.I. Soldatova) who had studied long-term variations of freeze-up and break-up dates in different geographical zones of Russia in 1891-1985 and their relationship with air temperature fluctuations in the Northern Hemisphere revealed unidirectional trends in variations of freeze-up and break-up dates with similar ice regime conditions [1].

Since the end of the 1990s, research in changes of ice regime of surface water bodies began at the State Hydrological Institute (St. Petersburg, Russia). Case studies of individual rivers and water bodies were used initially also with respect to freeze-up and break-up dates. In general, trends in long-term changes of the freeze-up and break-up dates over the past 50 - 100 years were analyzed [2]. Over the subsequent 10 years, the scope of characteristics to be analyzed was extended to include changes in ice cover duration and maximum ice thickness. It was found that the period since the beginning of the 1980's has seen the sharp rise in the degree of changes in water bodies ice regime [3] [4]. These changes are diverse for water bodies located in different natural zones. The main focus in these studies was on the Arctic rivers of Russia [5].

Outside Russia, since the end of the 1990s, the most extensive research was done in Canada, Finland and the USA [6] [7] [8]. In the last decade of the XX century, scientists from the USA initiated an international project on assessment of historical trends of freeze-up and break-up dates on rivers and lakes in the Northern Hemisphere. The project involved scientists from Canada and Finland and the outputs were published in the Science Journal [9]. Further studies in this field were mainly done in Canada (T. Prowse, B. R. Bonsal, C. R. Duguay).

An important step in international research activities was the establishment of the SWIPA (Snow, Water, Ice and Permafrost in the Arctic) project under the 
auspices of AMAP (Arctic Monitoring and Assessment Programme). The findings of the project have been summarized in a fundamental monograph with a specific chapter Lake and river ice addressing changes in the ice regime of the Arctic surface water bodies [10] [11] [12]. The author of the present article was the co-author of the chapter. It should be noted that research conducted outside Russia mainly focus on freeze-up and break-up dates and assessment of their trends.

Looking at the Russian research activities, one can outline the following major findings:

1. Determined are the features of long-term changes in river and lake ice regime, both for separate natural regions and for individual water bodies.

2. Revealed is a clear trend towards strengthening of the gradient of changes in ice regime characteristics since the early 1980's. The role of the climate component in these changes is not so clear.

3. There have been only general efforts to assess future changes in surface water bodies ice regime. The methodology for such assessment is currently at an early stage of development.

In view of the above, there is a need to enhance the research, first, in further development of methodologies to assess past and, especially, expected future changes in river and lake ice regime in close connection with climate indicators and their projected changes. Secondly, the scope of the research should be extended to include more rivers and lakes of Russia for which such assessments are made, including for the next 15 - 20 years.

The present article describes the findings of the research in changes of the ice regime characteristics of rivers and lakes located in the main natural zones of Russia over the past three decades.

\section{Methodology and Input Data}

Long-term series of ice cover duration and maximum ice thickness from the Water Cadastre of Russia were used as input data. Ice cover duration is a period since the appearance of stationary ice on a river or lake in autumn until the start of ice drift in spring.

Data from 28 gauging sites on 21 river and 10 observing sites on 8 lakes in all major natural regions of Russia were used in the assessment. All input information and data were downloaded in a special electronic database. Figure 1 provides a sketch map of observing sites on rivers and lakes used in the assessment.

The criteria for selection of sites was the length of time series which were generally not shorter than 55 - 56 years ending in 2010 (in some cases in 2008 or 2009). Table 1 presents information on observing sites in rivers used for the assessment.

The information on lake sites used in the assessments is presented in the $\mathrm{Ta}$ ble 2.

To assess changes in ice regime characteristics a comparative analysis of mean values as well as their trends was made for the three specific periods (entire pe- 
Table 1. Observing sites on rivers and length of observation periods.

\begin{tabular}{|c|c|c|c|c|}
\hline \multirow[b]{2}{*}{$N^{\circ}$} & \multirow[b]{2}{*}{ River-site } & \multirow{2}{*}{$\begin{array}{c}\text { Catchment area, } \\
\mathrm{km}^{2}\end{array}$} & \multicolumn{2}{|c|}{ Observation period } \\
\hline & & & $\begin{array}{l}\text { Ice cover } \\
\text { duration }\end{array}$ & $\begin{array}{l}\text { Maximum } \\
\text { ice thickness }\end{array}$ \\
\hline \multicolumn{5}{|c|}{ European Russia } \\
\hline 1. & Luga-Tolmachevo & 6350 & $1937-2010$ & $1954-2010$ \\
\hline $2 .$. & Onega-Turchasovo & 42,800 & $1933-2010$ & $1953-2010$ \\
\hline 3. & Northern Dvina-Kotlas & 88,300 & $1933-2010$ & $1954-2010$ \\
\hline 4. & Mezen'-Marakaib & 6450 & $1932-2010$ & $1953-2010$ \\
\hline 5. & Mezen'-Malonisogorskaya & 56,400 & $1945-1979$ & $1935-2010$ \\
\hline $6 .$. & Pechora-Ust'-Unya & 4430 & $1945-2010$ & $1955-2010$ \\
\hline 7. & Pechora-Troitsko-Pechorsk & 35,600 & 1914-2010 & $1955-2010$ \\
\hline 8. & Don-Serafimovich & 204,000 & $1980-2008$ & $1951-2008$ \\
\hline 9. & Volga-V. Lebyazhye & $1,360,000$ & $1980-2008$ & $1943-2008$ \\
\hline 10. & Samara-Elshanka & 22,800 & $1980-2008$ & $1945-2008$ \\
\hline \multicolumn{5}{|c|}{ Asian Russia } \\
\hline 11. & Ural-Verkhneuralsk & 2650 & $1980-2010$ & $1945-2010$ \\
\hline 12. & Ob'-Kamen-na-Obi & 216,000 & 1980-2009 & 1954-2009 \\
\hline 13. & Ob'-Oktyabrskoye & $2,190,000$ & 1980-2009 & $1954-2008$ \\
\hline 14. & Ob'-Salekhard & $2,950,000$ & 1980-2009 & 1954-2009 \\
\hline 15 & Yset'-Ysetskoye & 56,000 & $1980-2008$ & $1943-2008$ \\
\hline 16. & Biya-Biysk & 36,900 & $1980-2008$ & $1945-2008$ \\
\hline 17. & Tom'-Tomsk & 57,000 & $1980-2008$ & $1947-2008$ \\
\hline 18 & Yenisei-Kyzyl & 115,000 & $1980-2010$ & $1954-2010$ \\
\hline 19. & Yenisei-Selivanikha & $2,340,000$ & $1980-2010$ & $1954-2010$ \\
\hline 20. & Lena-Macha & 538,000 & $1980-2010$ & $1955-2010$ \\
\hline 21. & Lena-Sangari & $1,680,000$ & $1980-2010$ & $1955-2010$ \\
\hline 22. & Lena-Kyusyur & $2,430,000$ & $1980-2010$ & $1955-2010$ \\
\hline 23. & Barguzin-Mogoito & 9350 & $1980-2008$ & $1945-2008$ \\
\hline 24. & Shilka-Sretensk & 175,000 & 1980-2009 & $1955-2009$ \\
\hline 25. & Kolyma-Zyryanka & 287,000 & $1980-2010$ & $1941-2010$ \\
\hline 26. & Naiba-Bykob & 679 & $1980-2008$ & $1955-2008$ \\
\hline 27. & Ussuri-Kirovskiy & 24,400 & $1980-2010$ & $1956-2010$ \\
\hline 28. & Ingoda-Ulety & 12,500 & 1980-2009 & $1955-2009$ \\
\hline
\end{tabular}




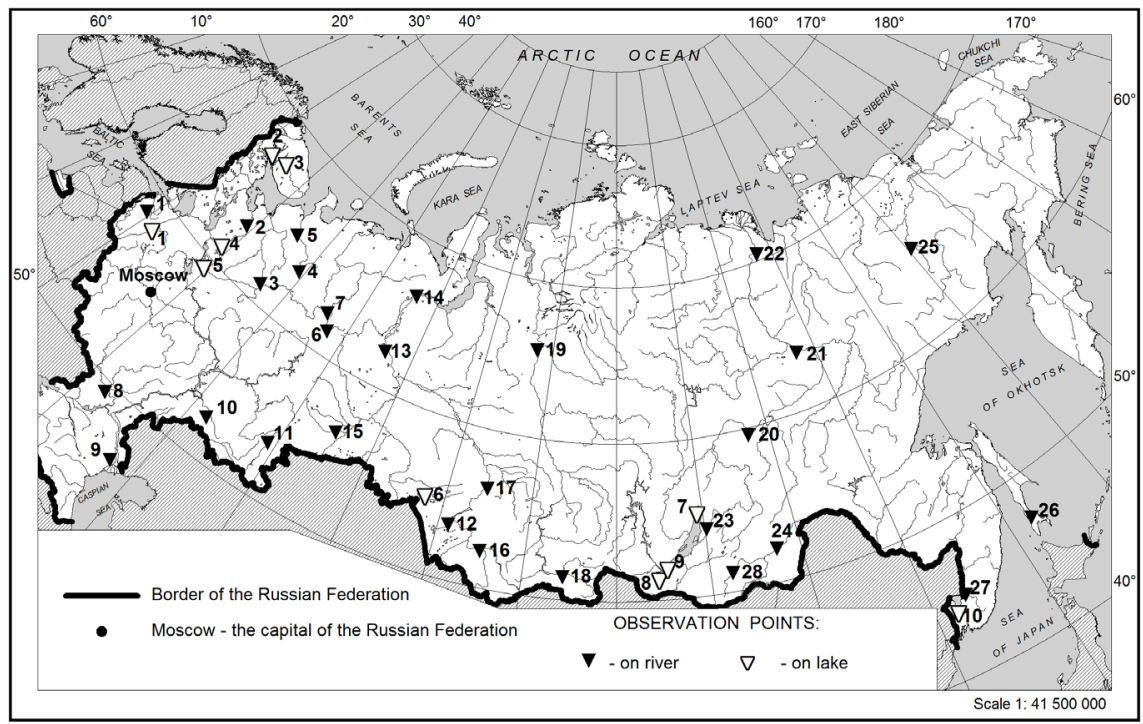

Figure 1. Observing sites on rivers and lakes.

Table 2. Observing sites on lakes and length of observation periods.

\begin{tabular}{ccccc}
\hline & & & \multicolumn{2}{c}{ Observation period } \\
\cline { 4 - 5 }$N^{\circ}$ & Lake-site & Area, $\mathrm{km}^{2}$ & $\begin{array}{c}\text { Ice cover } \\
\text { duration }\end{array}$ & $\begin{array}{c}\text { Maximum ice } \\
\text { thickness }\end{array}$ \\
\hline 1. & & 982 & $1916-1980$ & $1946-1980$ \\
2. & Ilmen'-Voitsy & 876 & $1945-2008$ & $1945-2008$ \\
3. & Lovozero-Lovozero & 200 & $1946-2008$ & $1946-2008$ \\
4. & Lacha-Nokola & 356 & $1918-2008$ & $1940-2008$ \\
5. & Kubenskoye-Korobovo & 370 & $1931-2008$ & $1932-2008$ \\
6. & Chany-Kvashnino & 1030 & $1933-2010$ & $1943-2010$ \\
7. & Baikal-Nizhneangarsk & 31,500 & $1936-2008$ & $1946-2008$ \\
8. & Baikal-Baikal & 31,500 & $1926-1980$ & $1945-2009$ \\
9. & Baikal-Peschanaya Bukhta & 31,500 & $1931-2008$ & $1945-2008$ \\
10. & Khanka-Astrakhanka & 4070 & $1936-2008$ & $1945-2008$
\end{tabular}

riod-since the beginning of observations until 2010, first stationary climate period-since the beginning of observations until 1979 and second non-stationary climate period-1980-2010).

\section{Assessment of Homogeneity of Long-Term Ice Regime Series}

Two general criteria were used to assess the homogeneity of long-term series of ice cover duration and maximum ice thickness, namely the Student's t-test (assessment of homogeneity hypothesis by true mean (expectation)) and the Fisher's F-test (assessment of homogeneity hypothesis by dispersion). Both criteria were used for $5 \%$ level of significance. The initial series included two abovemen- 
tioned periods - from the beginning of observations until 1979 and from 1980 to 2010. Table 3 below provides the results of long-term series homogeneity assessments for maximum ice thickness on rivers.

Analysis of data in Table 3 demonstrated that for maximum ice cover on rivers the homogeneity hypothesis has proved not to be true by both criteria for seven gauging sites (Luga-Tolmachevo, Northen Dvina-Kotlas, Mezen'-Marakaib, Pechora-Ust'-Unya, Ob'-Oktyabrskoye, Biya-Biysk and Lena-Kyusyur). Looking ahead, one can mention that for the above gauging sites the analysis of trends (to be discussed below) demonstrated either multidirectional trends in the first and second periods (Northen Dvina-Kotlas, Pechora-Ust'-Unya, Ob'Oktyabrskoye, Biya-Biysk) or highly different trend gradients when comparing two periods (Luga-Tolmachevo, Mezen'-Marakaib, Lena-Kyusyur). The same

Table 3. Homogeneity tests for long-term series of maximum ice thickness on rivers.

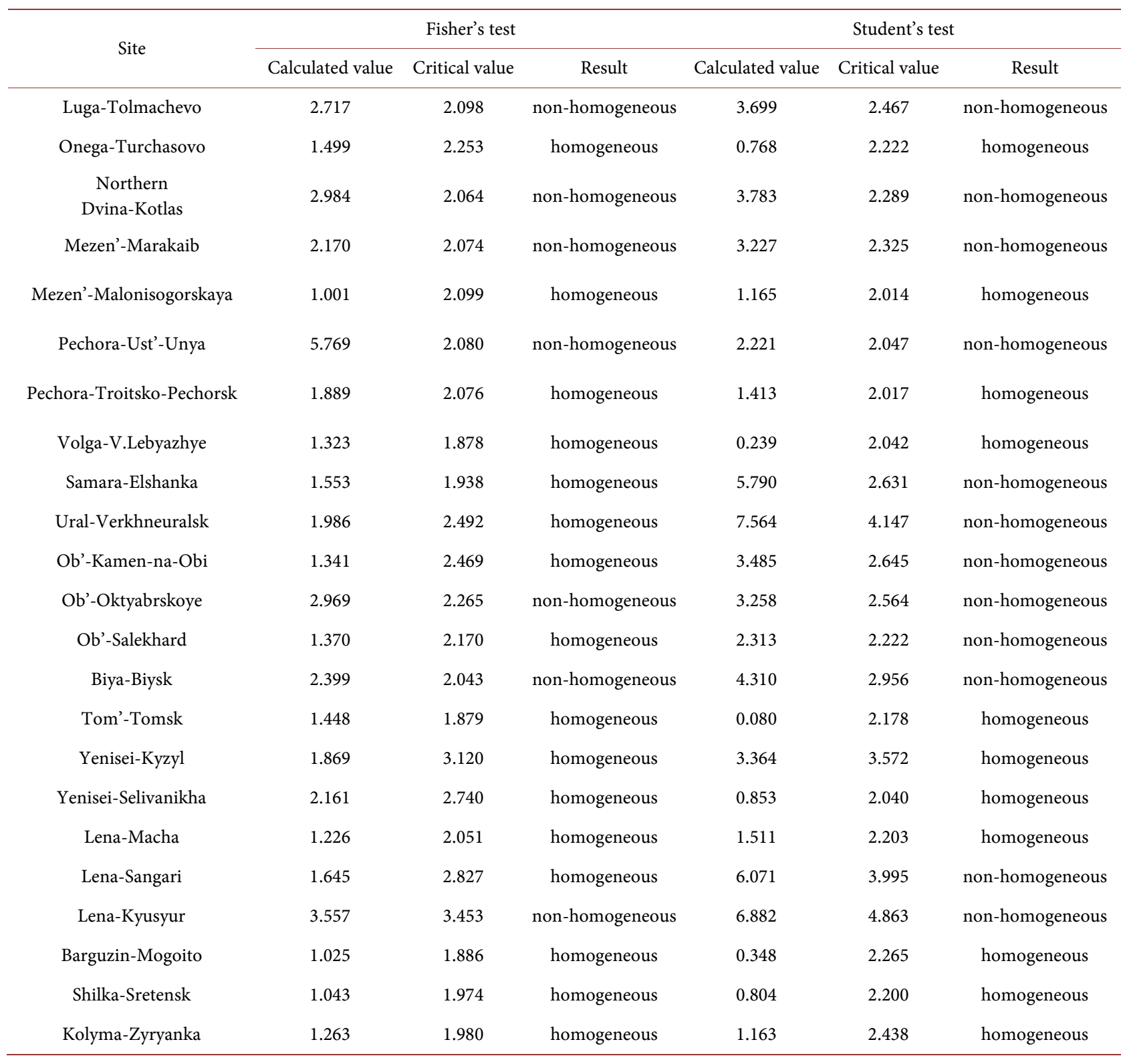


reasons lie behind cases when non-homogeneity is determined by one of the criteria. The homogeneity hypothesis by the Student's test has proved not to be true for the cases when trend gradients vary greatly for two periods (Ob'-Kamen'na-Obi, Ob'-Salekhard, Ural-Verkhneuralsk, Lena-Sangary), which can be explained by differences in mean values for both periods.

In regard to the long-term series of ice cover duration on rivers, the homogeneity hypothesis has proved not to be true by both criteria only for the Mezen'-Marakaib gauging site (as well as for the maximum ice thickness).

Long-term series of ice thickness on lakes have proved to be homogeneous by both criteria for five gauging sites. It is only for one site (lake Kubenskoye-Kubenskoye) that the hypothesis has proved not to be true by both criteria. The main reason for that are different trend gradients for both periods. The same reason lies behind non-homogeneity by Student's test of maximum ice thickness long-term series of the lakes Lacha-Nokolo and Khanka-Astrakhanka.

Long-term series of ice cover duration for six lake observing sites have proved to be homogeneous by both criteria. It is only for two sites (lake Baikal-Baikal and lake Khanka-Astrakhanka) that the time series have proved non-homogeneous by the Student's t-test, which, judging by the trend analysis, can be explained by differences in trend gradients for both periods and, accordingly, by differences in mean values for both periods.

Summarizing the results of the assessment, a very important trend can be observed: if time series of maximum ice thickness of an observing site are non-homogeneous by both criteria, the same is the case for the time series of duration of ice cover by both or only one criteria. The examples of such sites on rivers are Luga-Tolmachevo, Northen Dvina-Kotlas and Mezen'-Marakaib. This can be explained by the fact that sharp fluctuations of average ice cover duration for a long period are usually accompanied by changes in average maximum ice thickness for the same period. For example, if a series of harsh winters with prolonged ice cover duration is observed, average maximum ice thickness increases for the same period and vice versa.

\section{Assessment of Trends of Long-Term Series of Ice Regime Characteristics}

Trends of long-term series were assessed by the Student's t-test for three time intervals. Table 4 provides the results of the assessment for maximum ice thickness.

The table provides the following values needed to check the trend significance (i.e. to test the hypothesis of the ice regime characteristics linear regression coefficient equal zero):

$$
t=a / S_{a}
$$

where $a$-the regression coefficient, $S_{a}$-its root-mean-square deviation, $\mathrm{t}_{0.05}(\mathrm{~m})$ critical value to test the hypothesis of regression coefficient with $5 \%$ level of significance (inverse $t$-Student distribution) equal zero; $m$-degree of freedom for t-test (number of terms in a series minus 2). 
Table 4. Assessment of trends of long-term series of maximum ice thickness on rivers.

\begin{tabular}{|c|c|c|c|c|c|c|c|c|c|}
\hline \multirow{3}{*}{ Site } & \multicolumn{9}{|c|}{ Maximum ice thickness } \\
\hline & \multicolumn{3}{|c|}{ until 1980} & \multicolumn{3}{|c|}{ since 1980} & \multicolumn{3}{|c|}{ entire period } \\
\hline & $\mathrm{T}$ & $\mathrm{t}_{0.05}(\mathrm{~m})$ & $\mathrm{m}$ & $\mathrm{t}$ & $\mathrm{t}_{0.05}(\mathrm{~m})$ & $\mathrm{m}$ & $\mathrm{t}$ & $\mathrm{t}_{0.05}(\mathrm{~m})$ & $\mathrm{m}$ \\
\hline Luga-Tolmachevo & -1.449 & 2.069 & 24 & -4.101 & 2.052 & 27 & -6.522 & 2.007 & 55 \\
\hline Onega-Turchasovo & -0.942 & 2.060 & 25 & -1.765 & 2.086 & 20 & -3.734 & 2.012 & 56 \\
\hline Northern Dvina-Kotlas & -2.543 & 2.064 & 24 & 1.228 & 2.045 & 29 & -3.945 & 2.004 & 55 \\
\hline Mezen'-Marakaib & 1.848 & 2.060 & 25 & -1.305 & 2.080 & 21 & -4.224 & 2.011 & 56 \\
\hline Mezen'-Malonisogorskaya & -0.305 & 2.060 & 24 & -0.957 & 2.080 & 21 & -1.655 & 2.011 & 55 \\
\hline Pechora-Ust'-Unya & -0.311 & 2.069 & 23 & 0.402 & 2.080 & 21 & -1.588 & 2.013 & 54 \\
\hline Pechora-Troitsko-Pechorsk & -0.178 & 2.069 & 23 & -2.026 & 2.048 & 28 & -0.294 & 2.006 & 54 \\
\hline Don-Serafimovich & -0.409 & 2.056 & 27 & -1.249 & 2.093 & 19 & -2.338 & 2.012 & 56 \\
\hline Volga-V.Lebyazhye & 0.578 & 2.035 & 35 & -3.630 & 2.074 & 22 & -1.044 & 2.002 & 64 \\
\hline Samara-Elshanka & -2.077 & 2.035 & 33 & -1.770 & 2.056 & 26 & -7.118 & 2.000 & 62 \\
\hline Ural-Verkhneuralsk & -3.388 & 2.035 & 33 & -3.632 & 2.042 & 30 & -10.277 & 1.997 & 64 \\
\hline Ob'-Kamen-na-Obi & -0.485 & 2.069 & 24 & -1.483 & 2.048 & 28 & -4.139 & 2.006 & 54 \\
\hline Ob'-Oktyabrskoye & -0.678 & 2.069 & 24 & 0.516 & 2.069 & 23 & -2.055 & 2.011 & 53 \\
\hline Ob'-Salekhard & -3.623 & 2.069 & 24 & -0.004 & 2.069 & 23 & -2.352 & 2.011 & 54 \\
\hline Yset'-Ysetskoye & -0.946 & 2.030 & 35 & -1.808 & 2.080 & 21 & -4.251 & 2.002 & 64 \\
\hline Biya-Biysk & -1.967 & 2.035 & 33 & 0.541 & 2.056 & 26 & -3.978 & 2.000 & 62 \\
\hline Tom'-Tomsk & 1.428 & 2.042 & 31 & -1.447 & 2.056 & 26 & -0.305 & 2.002 & 60 \\
\hline Yenisei-Kyzyl & -1.638 & 2.074 & 24 & -1.017 & 2.045 & 29 & -6.522 & 2.006 & 55 \\
\hline Yenisei-Selivanikha & -0.333 & 2.080 & 24 & 0.557 & 2.045 & 29 & -0.755 & 2.007 & 55 \\
\hline Lena-Macha & 1.747 & 2.074 & 23 & -0.821 & 2.042 & 30 & -1.733 & 2.005 & 54 \\
\hline Lena-Kyusyur & -1.895 & 2.074 & 23 & -2.440 & 2.042 & 30 & -8.249 & 2.005 & 54 \\
\hline Barguzin-Mogoito & -1.529 & 2.037 & 37 & 1.387 & 2.060 & 25 & 0.619 & 2.001 & 52 \\
\hline Shilka-Sretensk & -0.961 & 2.069 & 23 & -0.513 & 2.052 & 27 & -1.337 & 2.007 & 53 \\
\hline Kolyma-Zyryanka & -2.387 & 2.040 & 31 & -0.015 & 2.045 & 29 & -1.156 & 1.999 & 68 \\
\hline Naiba-Bykob & -1.769 & 2.069 & 23 & 0.198 & 2.069 & 23 & -0.925 & 2.011 & 52 \\
\hline Ussuri-Kirovskiy & 1.045 & 2.074 & 22 & -0.541 & 2.045 & 29 & -0.647 & 2.006 & 53 \\
\hline Ingoda-Ulety & -0.129 & 2.074 & 23 & 0.731 & 2.052 & 27 & -1.241 & 2.008 & 53 \\
\hline
\end{tabular}

The test of hypothesis of the regression coefficient equal zero consisted in comparison of absolute value $t$ with $\mathrm{t}_{0.05}(\mathrm{~m})$. If $|\mathrm{t}|>\mathrm{t}_{0.05}(\mathrm{~m})$, the hypothesis is discarded with error probability 0.05 (trend is significant). If not, there is no reason to discard the hypothesis (the trend is insignificant).

Calculated and critical statistical values for the periods with statistically significant trends are shown in bold.

The analysis of trends demonstrated that maximum number of statistically significant trends of long-term series of maximum ice thickness on rivers (14 
cases out of 28) are obtained for the entire period. As for the two separate periods, the number of statistically significant trends is much smaller (four trends for the first period and three-for the second). It is noteworthy that statistically significant trends for complete time-series have been obtained for many gauging sites with non-homogeneous long-term series (Luga-Tolmachevo, Northen Dvina-Kotlas, Mezen'-Marakaib, Ob'-Oktyabrskoye, Biya-Biysk, Lena-Kyusyur), which is indicative of past changes in maximum ice thickness formation conditions in the past 60 - 70 years. Figure 2 shows as an example a diagram of changes in maximum ice thickness on the Lena river at Kyusyur site which gives visual representation of the trend for 1955-2010.

As for long-term series of ice cover duration, it is only for seven gauging sites that total assessment of trends was made for all the three periods. For the rest of the sites, assessment was made only for the second period due to absence of data.

For all the three periods, statistically significant trends were obtained for the same sites as they were obtained for maximum ice thickness but not always for the same periods. For example, for the Luga-Tolmachevo site, statistically significant trend was obtained for the entire period, while for the Northen DvinaKotlas, Mezen'-Marakaib and Pechora-Troitsko-Pechorsk they were obtained only for the first period (Figure 3) and for Ural-Verkhneuralsk-for the second one.

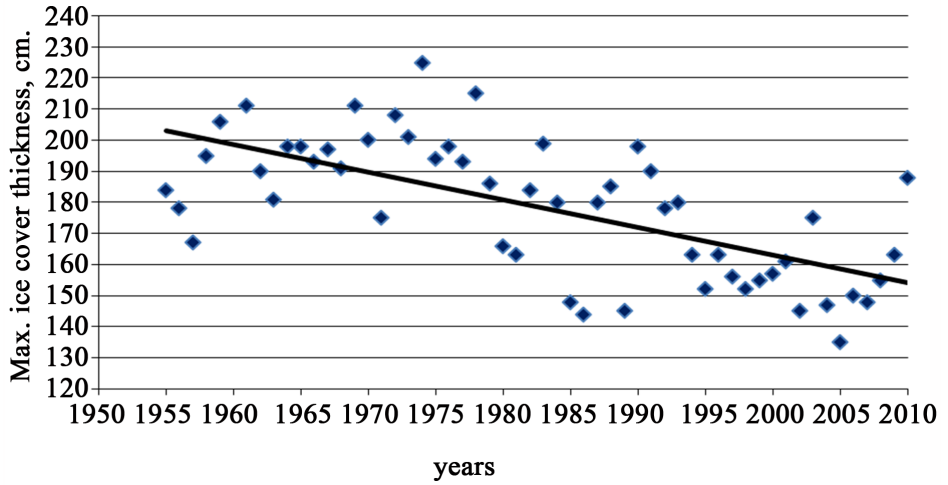

Figure 2. Changes in annual maximum ice thickness in 1955-2010 (Lena-Kyusyur).

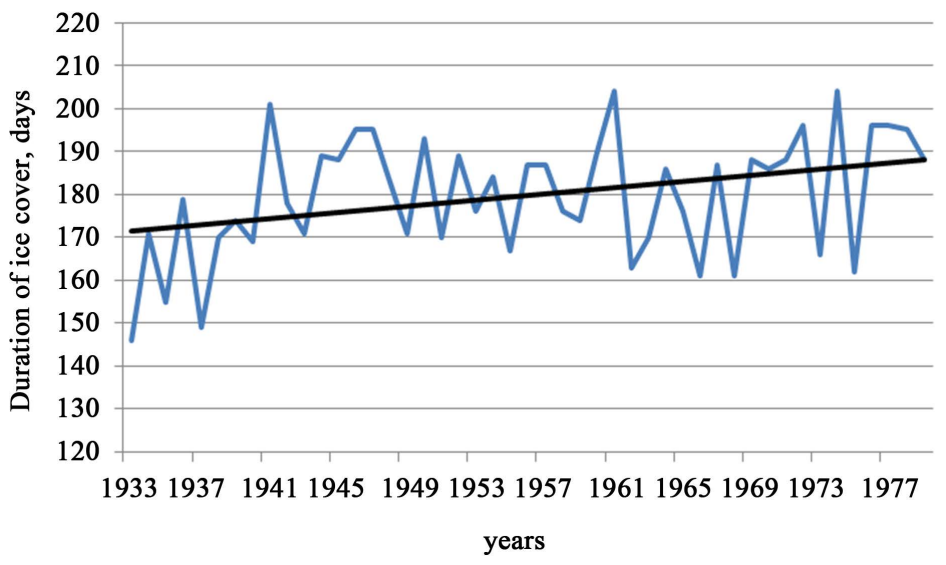

Figure 3. Changes in annual ice cover duration in 1933-1979 (Northen Dvina-Kotlas). 
For those sites which had time-series only for the second period, statistically significant trends were obtained for the sites Iset'-Isetskoye, Yenisei-Selivanikha, Lena-Macha, Lena-Kyusyur, Ussuri-Kirovskiy and Kolyma-Zyryanka. It is worth noting that for four out of six abovementioned sites statistically significant trends were obtained also for time-series of maximum ice thickness.

Statistically significant trends in long-term series of maximum ice thickness on lakes were obtained for the lakes Ilmen-Voitsy and Kubenskoye-Korobovo (entire series and second period), Imandra-Zasheek, Lovozero-Lovozero (second period) and Chany-Kvashnino (entire period) (Figure 4).

For the series of ice cover duration, statistically significant trends were obtained for the lakes Imandra-Zasheek, Lovozero-Lovozero (first period), ChanyKvashnino, Khanka-Astrakhanka (entire series and second period) and BaikalBaikal (entire series). It is easy to show that for three abovementioned lakes statistically significant trends were obtained for both maximum ice thickness and ice cover duration (Imandra-Zasheek, Lovozero-Lovozero, Chany-Kvashnino. It should also be noticed that long-term series of maximum ice thickness for $\mathrm{Ku}$ benskoye-Korobovo, for which a significant trend was obtained, proved to be non-homogeneous as well as ice cover duration series with significant trends for Baikal-Baikal and Khanka-Astrakhanka.

\section{Assessment of Changes in Ice Regime Characteristics of Rivers and Lakes for Non-Stationary Climate Period}

Changes in ice regime characteristics were assessed for the second period 19802010 relative to the first period of conditionally stationary climate (since the beginning of observations until 1979). Large scale chronological graphs of annual values of ice regime characteristics with frequent divisions of vertical axis spacing for 1980-2010 for all sites on lakes and rivers were used for this purpose. Trend lines were plotted on the graphs and values corresponding to the last and the first years in the series were taken. Difference of these two relative to a num-

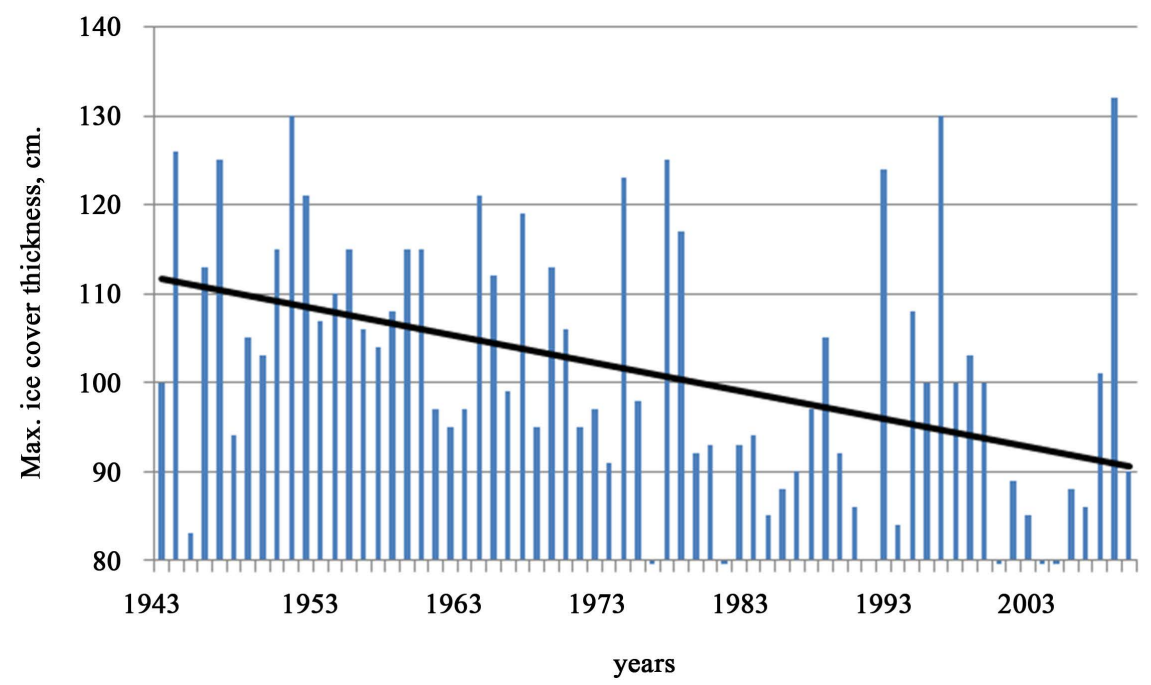

Figure 4. Changes in annual maximum ice thickness in 1943-2010 (Chany-Kvashnino). 
ber of years in a series defines the gradient $(\Delta)$ of temporal changes of a parameter. For the sake of convenience, the gradients were calculated relative to a decade and expressed either in $\mathrm{cm} /$ decade (for maximum ice thickness series) or in day/decade (for ice cover duration series). In order to evaluate the degree of significance of the obtained trends they were related to mean values of the corresponding characteristics calculated for the stationary climate period (since the beginning of observations until 1979). Table 5 and Table 6 provide changes in ice regime characteristics of rivers (\%) characterized by coefficient $\mathrm{K}$ calculated as a reminder of the gradient obtained for the series since 1980 (expressed as $\Delta \mathbf{X}_{2}$ for maximum ice thickness and $\Delta \mathbf{Y}_{2}$, for ice cover duration) and average value of a characteristic for the series until 1979 (expressed as $\mathbf{X}_{1}$ for maximum ice thickness and $\mathbf{Y}_{1}$ for ice cover duration).

Table 5. Changes in ice regime characteristics of rivers $\mathrm{K}(\%)$ by trends for the second period relative to their mean values for the first period.

\begin{tabular}{|c|c|c|c|c|c|c|}
\hline \multirow{2}{*}{ River site } & \multicolumn{3}{|c|}{ Maximum ice thickness } & \multicolumn{3}{|c|}{ Ice cover duration } \\
\hline & $\mathbf{X}_{1, \mathrm{~cm} .}$ & $\Delta \mathbf{X}_{2, \mathrm{~cm}}$ & $\mathrm{~K}, \%$ & $\mathbf{Y}_{1, \text { days }}$ & $\Delta \mathbf{Y}_{2, \text { days }}$ & $\mathrm{K}, \%$ \\
\hline Luga-Tolmachevo & 42 & -15 & 35 & 115 & -9 & 8 \\
\hline Onega-Turchasovo & 62 & -9 & 14 & 169 & -21 & 12 \\
\hline Northern Dvina-Kotlas & 73 & +6 & 8 & 180 & -12 & 7 \\
\hline Mezen'-Marakaib & 78 & -5 & 6 & 204 & -4 & 20 \\
\hline Mezen'-Malonisogorskaya & 80 & -6 & 7 & 201 & -9 & 4 \\
\hline Pechora-Ust'-Unya & 72 & +3 & 4 & 204 & -15 & 7 \\
\hline Pechora-Troitsko-Pechorsk & 68 & -9 & 13 & 192 & 0 & \\
\hline Volga-V. Lebyazhye & 43 & -24 & 56 & & & \\
\hline Samara-Elshanka & 49 & -12 & 24 & & & \\
\hline Ural-Verkhneuralsk & 94 & -24 & 25 & & & \\
\hline Don-Serafimovich & 43 & -18 & 42 & & & \\
\hline Ob'-Kamen-na-Obi & 89 & -9 & 10 & & & \\
\hline Ob'-Oktyabrskoye & 85 & +6 & 7 & & & \\
\hline Ob'-Salekhard & 105 & 0 & & & & \\
\hline Yset'-Ysetskoye & 72 & -21 & 29 & & & \\
\hline Biya-Biysk & 64 & 0 & & & & \\
\hline Tom'-Tomsk & 82 & -12 & 15 & & & \\
\hline Yenisei-Kyzyl & 158 & -15 & 9 & & & \\
\hline Yenisei-Selivanikha & 90 & +2 & 2 & & & \\
\hline Lena-Macha & 116 & -9 & 8 & & & \\
\hline Lena-Kyusyur & 192 & -15 & 8 & & & \\
\hline Barguzin-Mogoito & 117 & +18 & 15 & & & \\
\hline Shilka-Sretensk & 124 & -18 & 14 & & & \\
\hline Kolyma-Zyryanka & 97 & 0 & & & & \\
\hline Naiba-Bykob & 79 & 0 & & & & \\
\hline Ussuri-Kirovskiy & 85 & -5 & 6 & & & \\
\hline Ingoda-Ulety & 135 & +9 & 7 & & & \\
\hline
\end{tabular}


Table 6. Changes in ice regime characteristics (\%) obtained from trends for the second period relative to their mean values for the first period.

\begin{tabular}{ccccccc}
\hline \multirow{2}{*}{ Site } & \multicolumn{3}{c}{ Maximum ice thickness } & \multicolumn{3}{c}{ Ice cover duration } \\
\cline { 2 - 7 } & $\mathrm{X}_{1, \mathrm{~cm}}$ & $\Delta \mathrm{X}_{2, \mathrm{~cm}}$ & $\mathrm{~K}, \%$ & $\mathrm{Y}_{1, \text { days }}$ & $\Delta \mathrm{Y}_{2, \mathrm{days}}$ & $\mathrm{K}, \%$ \\
\hline Ilmen'-Voitsy & 65 & -3 & 5 & 175 & +5 & 3 \\
Imandra-Zasheek & 79 & -21 & 26 & 200 & -14 & 7 \\
Lovozero-Lovozero & 93 & -18 & 19 & 225 & +15 & 7 \\
Lacha-Nokola & 99 & +6 & 6 & 177 & -15 & 8 \\
Kubenskoye-Korobovo & 67 & -12 & 18 & 155 & +7 & 4 \\
Chany-Kvashnino & 107 & 0 & & 199 & +14 & 7 \\
Baikal-Nizhneangarsk & 100 & -12 & 12 & 142 & +3 & 2 \\
Baikal-Baikal & 83 & -2 & 2 & 116 & -15 & 13 \\
Baikal-Peschanaya Bukhta & 91 & -4 & 4 & 113 & +3 & 3 \\
\hline
\end{tabular}

For some rivers, parameters related to ice cover duration are not reflected in Table 5 due to absence of data needed to calculate mean values of a parameter for the first period.

Analysis of data in Table 5 demonstrates that for many rivers gradients of changes in maximum ice thickness relative to mean value of a parameter for previous period amount to $15 \%$ and more. Such gradients are especially significant for southern rivers of the European Russia (Volga-Verkhnee Lebyazhye$56 \%$, Samara-Elshanka-24\%, Don-Belyaevsky-42\%). First, for these rivers mean values of the parameters for the first period are small $(43-49 \mathrm{~cm})$ compared with the same values, for example, for the Siberian rivers $(2-3$ times greater for maximum ice thickness). Secondly, for many rivers of the Asian Russia these gradients are equal to or $10 \%$ greater than mean values for the previous period (Ob'-Kamen-na-Obi, Tom'-Tomsk, Yset'-Ysetskoye, Barguzin-Mogoito, Shilka-Sretensk), although these mean values themselves are quite large amounting to $80-120 \mathrm{~cm}$.

As for the relations of gradients of ice cover duration to mean values of this parameter for the first period, they do not exceed $10 \%-15 \%$ for the rivers in question, from which it can be concluded that changes in maximum ice thickness for the past 30-year period occur more intensively than those in ice cover duration.

Data in Table 6 indicate that maximum values of coefficient $\mathrm{K}$ for maximum ice thickness are typical for lakes of the Kola Peninsula (Imandra-Zasheek$26 \%$, Lovozero-Lovozero-19\%) and for the lake Kubenskoye-Korobovo (18\%). For the rest of the lakes these coefficients do not exceed $10 \%-12 \%$.

Interestingly, as opposed to rivers, the range of changes in mean values of maximum ice thickness for the first period for lakes of both European and Asian Russia is much smaller and varies within $65-107 \mathrm{~cm}$. Values of the coefficient $\mathrm{K}$ for the lakes in question vary mainly from $2 \%$ to $8 \%$ (only for the lake Baikal- 
Baikal it amounted to 13\%), which proves the previous conclusion that for rivers changes in maximum ice thickness for the past 30 years occur more intensively compared with changes in ice cover duration.

A comparison was made of mean values of the characteristics in question obtained from time series of the second period with mean values of the same characteristics obtained from the first period time series. The results of the comparison are given in Table 7.

Analyzing data in Table 7 one can observe that in most cases values of changes in both maximum ice thickness and ice cover duration are negative. The largest negative changes are typical for rivers of the Asian Russia, e.g. for the site Ural-Verkhneuralsk they amounted to $-35 \mathrm{~cm}$, for Yenisei-Kyzyl and LenaKyusyur $-38 \mathrm{~cm}$. In most cases, the above changes for rivers do not exceed $10-$ $12 \mathrm{~cm}$. The latter is typical also for data on ice cover duration on rivers- negative changes in mean values for the second period relative to the first one are in the range of 10 days except for the Luga-Tolmachevo site for which it was 29 days.

For lakes, all the obtained changes in mean values of ice regime characteristics are negative and relatively small. For maximum ice thickness they were equal to 1 to $13 \mathrm{~cm}$ and for ice cover duration 3 to 12 days.

Three cases demonstrated positive values of changes for both maximum ice thickness (Yenisei-Selivanikha $+1 \mathrm{~cm}$; Barguzin-Mogoito $+19 \mathrm{~cm}$.) and ice cover duration (Onega-Turchasovo +3 days). It is worth noting that positive changes in mean values over the past period are not always indicative of positive trend of a parameter for the entire period (since the beginning of observations until 2010). It appeared negative for two out of three abovementioned sites (Yenisei-Selivanikha $-1 \mathrm{~cm} /$ decade; Onega-Turchasovo $-2 \mathrm{~cm} /$ decade) and only for the site Barguzin-Mogoito the trend of maximum ice cove thickness changes was positive for the entire period $(+2 \mathrm{~cm} /$ decade) .

In order to integrate assessments of changes in ice regime parameters of all the abovementioned rivers and lakes in 1980-2010, data on trends for the second period (Table 5 and Table 6) were integrated with assessment of changes in mean values for the non-stationary period (1980-2010) relative to mean values for the previous period (Table 7). Integrated values of changes in maximum ice thickness and ice cover duration over non-stationary period (1980-2010) relative to the previous period are given in Table 8 .

\section{Summary}

The study found that maximum ice thickness on the rivers of the European Russia in 1980-2010 decreased in general by $10 \%-15 \%$. It is only for the LugaTolmachevo site that this decrease amounted to more than 30\% compared with the previous period $(42 \mathrm{~cm})$. For the rivers of the Asian Russia, decrease in maximum ice thickness amounted to $10 \%$ - $20 \%$ except for the site UralVerkhneuralsk where it is estimated at $25 \%-35 \%$.

Ice-cover duration on the rivers of the European Russia decreased by $5 \%$ $10 \%$. It is estimated at $29 \%$ only for the Luga-Tolmachevo site. 
Table 7. Changes in mean values of maximum ice thickness and ice cover duration for the period of non-stationary climate (1980-2010) relative to mean values for the previous period.

\begin{tabular}{|c|c|c|}
\hline Water body-site & $\begin{array}{l}\text { Changes in mean values of } \\
\text { maximum ice thickness for the } \\
\text { second period (1980-2010) } \\
\text { relative to the first period, cm }\end{array}$ & $\begin{array}{l}\text { Changes in mean values of } \\
\text { ice cover duration for the } \\
\text { second period (1980-2010) } \\
\text { relative to the first period, days }\end{array}$ \\
\hline Luga-Tolmachevo & -12 & -29 \\
\hline Onega-Turchasovo & -7 & +3 \\
\hline Northern Dvina-Kotlas & -11 & -7 \\
\hline Mezen'-Marakaib & -9 & -11 \\
\hline Mezen'-Malonisogorskaya & -5 & -10 \\
\hline Pechora-Ust'-Unya & -5 & -8 \\
\hline Pechora-Troitsko-Pechorsk & -2 & -3 \\
\hline Volga-V. Lebyazhye & -3 & \\
\hline Don-Serafimovich & -8 & \\
\hline Samara-Elshanka & -10 & \\
\hline Ural-Verkhneuralsk & -35 & \\
\hline Ob'-Kamen-na-Obi & -18 & \\
\hline Ob'-Oktyabrskoye & -6 & \\
\hline Ob'-Salekhard & -2 & \\
\hline Yset'-Ysetskoye & -12 & \\
\hline Biya-Biysk & -10 & \\
\hline Tom'-Tomsk & -2 & \\
\hline Yenisei-Kyzyl & -38 & \\
\hline Yenisei-Selivanikha & +1 & \\
\hline Lena-Macha & -23 & \\
\hline Lena-Sangari & -23 & \\
\hline Lena-Kyusyur & -38 & \\
\hline Barguzin-Mogoito & +9 & \\
\hline Shilka-Sretensk & -4 & \\
\hline Kolyma-Zyryanka & -1 & \\
\hline Naiba-Bykob & -2 & \\
\hline Ussuri-Kirovskiy & -2 & \\
\hline Ingoda-Ulety & -8 & \\
\hline Ilmen'-Voitsy & -9 & -3 \\
\hline Imandra-Zasheek & -1 & -3 \\
\hline Lovozero-Lovozero & -9 & -9 \\
\hline Lacha-Nokola & -2 & -12 \\
\hline Kubenskoye-Korobovo & -2 & -11 \\
\hline Chany-Kvashnino & -13 & -12 \\
\hline Baikal-Nizhneangarsk & -8 & -8 \\
\hline Baikal-Baikal & -11 & -8 \\
\hline Baikal-Peschanaya Bukhta & -7 & -4 \\
\hline Khanka-Astrakhanka & -7 & -10 \\
\hline
\end{tabular}


Table 8. Assessment of changes in maximum ice thickness and ice cover duration over non-stationary climate period (1980-2010) relative to the previous period.

\begin{tabular}{|c|c|c|}
\hline Water body-Observing site & Maximum ice thickness, $\mathrm{cm}$ & Ice cover duration, $\mathrm{cm}$ \\
\hline Luga-Tolmachevo & $-12-15$ & $-9-29$ \\
\hline Onega-Turchasovo & $-7-9$ & $+3-21$ \\
\hline Northern Dvina-Kotlas & $+6-11$ & $-7-12$ \\
\hline Mezen'-Marakaib & $-5-9$ & $-4-11$ \\
\hline Mezen'-Malonisogorskaya & $-5-6$ & $-9-10$ \\
\hline Pechora-Ust'-Unya & $+3-5$ & $-8-15$ \\
\hline Pechora-Troitsko-Pechorsk & $-2-9$ & $0-3$ \\
\hline Don-Serafimovich & $-8-18$ & \\
\hline Volga-V. Lebyazhye & $-3-24$ & \\
\hline Samara-Elshanka & $-10-12$ & \\
\hline Ural-Verkhneuralsk & $-24-35$ & \\
\hline Ob'-Kamen-na-Obi & $-9-18$ & \\
\hline Ob'-Oktyabrskoye & $-2-6$ & \\
\hline Ob'-Salekhard & $0-2$ & \\
\hline Yset'-Ysetskoye & $-12-21$ & \\
\hline Biya-Biysk & $0-10$ & \\
\hline Tom'-Tomsk & $-2-12$ & \\
\hline Yenisei-Kyzyl & $-15-38$ & \\
\hline Yenisei-Selivanikha & $-1+2$ & \\
\hline Lena-Macha & $-9-23$ & \\
\hline Lena-Sangari & $-21-23$ & \\
\hline Lena-Kyusyur & $-15-38$ & \\
\hline Barguzin-Mogoito & $+9+15$ & \\
\hline Shilka-Sretensk & $-4-18$ & \\
\hline Kolyma-Zyryanka & $0-1$ & \\
\hline Naiba-Bykob & $0-2$ & \\
\hline Ussuri-Kirovskiy & $-2-5$ & \\
\hline Ingoda-Ulety & $-8+9$ & \\
\hline Ilmen'-Voitsy & $-3-9$ & $-3+3$ \\
\hline Imandra-Zasheek & $-1-21$ & $-3-12$ \\
\hline Lovozero-Lovozero & $-9-18$ & $-9+15$ \\
\hline Lacha-Nokola & $-2+6$ & $-12-15$ \\
\hline Kubenskoye-Korobovo & $-2-12$ & $-11+7$ \\
\hline Chany-Kvashnino & $0-13$ & $-12+12$ \\
\hline Baikal-Nizhneangarsk & $-8-12$ & $-8+3$ \\
\hline Baikal-Baikal & $-2-11$ & $-8-15$ \\
\hline Baikal-Peschanaya Bukhta & $-4-7$ & $-4+3$ \\
\hline Khanka-Astrakhanka & $-6-7$ & $-5-10$ \\
\hline
\end{tabular}


Maximum ice thickness on the above lakes decreased by $10 \%-15 \%$ in 1980 2010. As for decrease in ice cover duration, the negative gradient is estimated at $5 \%-10 \%$ compared with the previous period.

\section{References}

[1] Ginzburg, B.M. and Soldatova, I.I. (1996) Long-Term Oscillations of River Freezing and Breakup Dates in Different Geographical Zones. Russian Meteorology and Hydrology (Meteorologiya i gydrologiya), № 6, 101-108 (in Russian).

[2] Vuglinsky, V.S. (2001) Extremely Early and Late Dates of Lake Freezing and Ice Break-Up in Russia. Verhandlungen des Internationalen Verein Limnologie, 27, 2793-2795.

[3] Vuglinsky, V.S., Gronskaya, T.P. and Lemeshko, N.A. (2002) Long-Term Characteristics of Ice Events and Ice Thickness on the Largest Lakes and Reservoirs of Russia, "Ice in the Environment". Proceedings of the 16th International Symposium on Ice, 3, 88-91.

[4] Vuglinsky, V.S. and Gronskaya, T.P. (2006) Changes in Ice Regime of Russian Lakes and Rivers and Their Possible Impact on the Economy. In: Modern problems of hydrometeorology. Asterion, St. Petersburg, 229-244 (in Russian).

[5] Vuglinsky, V.S. (2002) Peculiarities of Ice Events in Russian Arctic Rivers. Hydrological Processes, 16, 905-913. https://doi.org/10.1002/hyp.365

[6] Kuusisto, E. and Elo, A. (2001) Lake and River Ice Variables as Climate Indicators in Northern Europe. Verhandlungen des Internationalen Verein Limnologie, 27, 2761-2764.

[7] Prowse, T. and Beltaos, S. (2002) Climatic Control of River-Ice Hydrology: A Review. Hydrological Processes, 16, 805-822. https://doi.org/10.1002/hyp.369

[8] Duguay, C., Prowse, T., Bonsal, B., Brown, R., Lacroix, M. and Menard, P. (2005) Recent Trends in Canadian Lake Ice Covers. Proceedings of the 61 st Eastern Snow Conference.

[9] Magnuson, J.J., Robertson, D.M., Benson, B.J., Wynne, R.H., Livingstone, D.M., Arai, T., Assel, R.A., Barry, R.G., Card, V., Kuusisto, E., Granin, N.G., Prowse, T.D., Stewar, K.M. and Vuglinsky, V.S. (2000) Historical Trends in Lake and River Cover in the Northern Hemisphere. Science, 289, 1743-1746.

https://doi.org/10.1126/science.289.5485.1743

[10] Prowse, T., Alfredsen, K., Beltaos, S., Bonsal, B.R., Bowden, W.B., Duguay, C.R., Korhola, A., McNamara, J., Vincent, W.F., Vuglinsky, V., Walter Anthony, K.M. and Weyhenmeyer, G.A. (2011) Effects of Changes in Arctic Lake and River Ice. $A M B I O, 40,63-74$. https://doi.org/10.1007/s13280-011-0217-6

[11] Prowse, T., Alfredsen, K., Beltaos, S., Bonsal, B., Duguay, C., Korhola, A., McNamara, J., Pienitz, R., Vincent, W.F., Vuglinsky, V. and Weyhenmeyer, G.A. (2011) Past and Future Changes in Lake and River Ice. $A M B I O, 40,53-62$. https://doi.org/10.1007/s13280-011-0216-7

[12] Prowse, T., Alfredsen, K., Beltaos, S., Bonsal, B., Duguay, C., Korhola, A., McNamara, J., Vincent, W.F., Vuglinsky, V. and Weyhenmeyer, G.A. (2011) Arctic Freshwater Ice and Its Climate Role. $A M B I O, 40,46-52$. https://doi.org/10.1007/s13280-011-0214-9 
Submit or recommend next manuscript to SCIRP and we will provide best service for you:

Accepting pre-submission inquiries through Email, Facebook, LinkedIn, Twitter, etc. A wide selection of journals (inclusive of 9 subjects, more than 200 journals)

Providing 24-hour high-quality service

User-friendly online submission system

Fair and swift peer-review system

Efficient typesetting and proofreading procedure

Display of the result of downloads and visits, as well as the number of cited articles Maximum dissemination of your research work

Submit your manuscript at: http://papersubmission.scirp.org/

Or contact nr@scirp.org 